\title{
CORRELATION BETWEEN OBESITY AND THYROTROPIN (TSH) IN CLINICALLY EUTHYROID SUBJECTS
}

\author{
Madhumita De ${ }^{1}$, Abhijit Rakshit ${ }^{2}$
}

${ }_{1}^{1}$ Assistant Professor, Department of Physiology, R. G. Kar Medical College, Kolkata, West Bengal, India.

${ }^{2}$ Associate Professor, Department of Obstetrics and Gynaecology, R. G. Kar Medical College, Kolkata, West Bengal, India.

\section{ABSTRACT}

\section{BACKGROUND}

Thyroid stimulating hormone (TSH, Thyrotropin) induces adipogenesis and adipokine production directly and may contribute to the evolution of obesity, independent of any involvement of the thyroid gland. This study has been conducted to evaluate the association of minor disturbances of thyroid function with changes in obesity indicators like Body Mass Index (BMI) \& Waist-Hip Ratio (WHR). We wanted to assess the correlation between the serum TSH level and the various obesity indicators.

\section{METHODS}

This study was conducted in the Department of Physiology, MGM Medical college, Kishanganj, Bihar, in collaboration with the Department of Biochemistry and Department of Gynaecology \& Obstetrics, between 2014 and 2016, among 200 medical and paramedical students (100 males and 100 females) attending classes in the Department of Physiology, found to be clinically euthyroid with no family history of thyroid disorder and no history of taking any medication which may affect the thyroid profile.

\section{RESULTS}

In this study the average height of males (1.76 \pm 0.055 metres) is greater than the average height of females $(1.58 \pm 0.077$ metres). Average weight is also higher in males $(85.14 \pm 11.181 \mathrm{kgs})$ than females $(61.20 \pm 11.963 \mathrm{kgs})$. Therefore, in this study BMI is more in males $\left(27.61 \pm 4.790 \mathrm{~kg} / \mathrm{m}^{2}\right)$ in comparison to females $\left(25.59 \pm 5.109 \mathrm{~kg} / \mathrm{m}^{2}\right)$. This observation regarding BMI contradicts the findings of Kota SK et al, ${ }^{16}$ Jung $\mathrm{CH}$ et al ${ }^{15}$ studies where the BMI is more in females than in males, whereas observation of Mahanta $\mathrm{M}$ et al ${ }^{17}$ is that BMI of males $\left(21.41 \pm 2.197 \mathrm{~kg} / \mathrm{m}^{2}\right)$ was slightly more than that of females $\left(21.36 \pm 2.995 \mathrm{~kg} / \mathrm{m}^{2}\right) \mathrm{which}$ to some extent corresponds with the findings of this study. Average Waist Circumference (WC) of males (0.89 \pm 0.093 metres) is greater than the average WC of females $(0.77 \pm 0.107$ metres) and average Hip Circumference (HC) is greater in males $(1.04 \pm 0.067$ metres $)$ than females $(0.97 \pm 0.102$ metres) in this study. Therefore, it has been observed that Waist-Hip Ratio (WHR) is more in males $(0.86 \pm 0.057)$ than in females $(0.78 \pm 0.048)$ in this study. Result of WHR in our study corroborates with observation of Mahanta M et $\mathrm{al}^{17}$ where WHR in male group $(0.84 \pm 0.059)$ was more than female group $(0.77 \pm 0.048)$.

\section{CONCLUSIONS}

There is no correlation between BMI and serum TSH levels in female subjects, whereas there is moderate direct correlation between TSH level and BMI, TSH level and Weight in male group and there is good inverse correlation between TSH level and WHR in female group and moderate inverse correlation between TSH level and Weight, TSH level and Waist Circumference in female subjects.

\section{KEY WORDS}

TSH, Body Mass Index (BMI), Waist Hip Ratio (WHR).

HOW TO CITE THIS ARTICLE: De M, Rakshit A. Correlation between obesity and thyrotropin (TSH) in clinically euthyroid subjects. J. Evolution Med. Dent. Sci. 2019;8(26):2045-2049, DOI: 10.14260/jemds/2019/451

\section{BACKGROUND}

Thyroid stimulating hormone (TSH, Thyrotropin), secreted by the thyrotrope cells of the anterior pituitary, plays a pivotal role in the control of the thyroid axis and serves as the most useful physiologic marker of thyroid action. ${ }^{1}$

Emerging evidence suggests that thyrotropin induces adipogenesis and adipokine production directly and may contribute to the evolution of obesity, independent of any involvement of the thyroid gland.2

Recent studies in man and other mammalian species have shown that adipocytes and preadipocytes possess

'Financial or Other Competing Interest': None.

Submission 08-05-2019, Peer Review 14-06-2019,

Acceptance 20-06-2019, Published 01-07-2019.

Corresponding Author:

Dr. Abhijit Rakshit,

Block-2, Flat-3c,

Shakuntala Garden, 609 Laskarhat,

Kolkata-700039, West Bengal, India.

E-mail: drabhijitr81@gmail.com

DOI: $10.14260 /$ jemds $/ 2019 / 451$ thyrotropin receptors.3,4 The signals generated by thyrotropin in adipocytes is mediated by the activation of cAMP dependant protein kinase. ${ }^{5}$ Studies in vitro and in vivo demonstrate that the action of thyrotropin via its receptors in fat tissues induces differentiation of preadipocytes into adipocytes and expansion of adipose tissue i.e. adipogenesis..$^{3,6}$

Adipose tissue is a major endocrine gland, producing numerous adipokines, which have metabolic and inflammatory effects on other tissues. ${ }^{7,8}$

Schaffer $\mathrm{A}$ et al ${ }^{4}$ proposed that a hypothalamic- pituitaryadipose tissue axis exists. The positive relationship between serum TSH and adiposity would be consistent with this concept in a downstream sense. Yet, such an axis would require a feedback system. Hence the positive relationship between serum TSH and adiposity could also be interpreted in the reverse. Among the adipokines, extensive information is available on the inhibition of appetite by Leptin, dominantly by acting on the hypothalamus. A positive correlation has been reported between serum levels of Leptin and TSH.10,11 
In recent years, there has been an increasing focus on subclinical thyroid dysfunction. Subclinical hypothyroidism, defined as an elevated serum TSH but with serum free thyroxine levels within the normal range, is associated with dyslipidaemia. 12

As overweight is associated with increased morbidity and disability, a study of relationship between thyroid function and body weight might be of importance. ${ }^{13}$ Until now, only a few epidemiological studies evaluating the association between the levels of thyroid hormones and TSH with body weight and BMI were carried out.

The Dan Thry study ${ }^{14}$ showed a positive correlation between BMI and category of TSH. Obesity (BMI $>30 \mathrm{~kg} / \mathrm{m}^{2}$ ) and serum TSH levels were significantly associated in this cohort study. A study showed that TSH was positively associated with waist circumference. 15 Another study found that patients with hypothyroidism exhibited higher waist-tohip ratios, an index of obesity. 16

It is obvious that thyroid dysfunction affects body weight, however, possible association of minor disturbances of thyroid function with changes in various anthropometric measurements related to obesity - Body Mass Index (BMI) \& Waist-Hip Ratio (WHR) need to be elucidated.

Thus, the present study "Correlation between obesity \& thyrotropin (TSH) in clinically euthyroid subjects" was undertaken.

\section{Aims \& Objectives}

1. To assess various anthropometric measurements related to obesity Height, Weight, Body Mass Index (BMI), Waist circumference, Hip circumference, Waist Hip Ratio (WHR) in the study population (Medical and Paramedical Students).

2. To measure the serum TSH level of the same subjects.

3. To assess the correlation between the serum TSH level and the various anthropometric measurements.

\section{METHODS}

The present study was conducted in the Department of Physiology, MGM Medical College, Kishanganj, Bihar in collaboration with the Department of Biochemistry and G \& O after getting ethical clearance. The period of study was between May 2014 to April 2016. The study was conducted among 200 medical and paramedical students (100 males and 100 females) attending classes in the Department of Physiology. The purpose and procedure of the study was explained to all participants. Detailed history was taken, general and systemic examinations were done.

\section{Exclusion Criteria}

1. Present or past history of any thyroid disorder.

2. Family history of any thyroid disorder.

3. History of intake of any medication which may affect the thyroid hormone profile such as, glucocorticoids, antithyroid drugs, thyroid hormone replacement, Oestrogen and Progesterone preparations.

4. History or clinical examination suggestive of any signs or symptoms related to thyroid disorder.

\section{Statistical Methods}

The data collected was tabulated and subjected to statistical analysis. All data were expressed as Mean \pm SD, an unpaired $t$ test, Correlations coefficients were calculated using MS Excel. Software used Statistica version 6 [Tulsa, Oklahoma: StatSoft Inc., 2001] \& MedCalc version 11.6 [Mariakerke, Belgium: Med Calc Software 2011].

The formula of Body Mass Index (BMI) calculation: $\frac{\text { Weight (in kilograms) }}{{\text { (Height in meters })^{2}}^{2}}$

Waist - Hip Ratio (WHR) will be calculated by the formula:

Waist circumference (in metres)

Hip circumference (in metres )

After taking history and conducting general and systemic examinations, subjects found to be clinically euthyroid were included in the study. Written informed consent was taken from all the subjects. For each subject, after measuring height, weight, waist circumference and hip circumference, blood samples were collected for estimation of TSH. Waist circumference was measured at the midpoint between the lower border of the rib cage and the iliac crest. The hip circumference measurement is taken at the level of the greatest protrusion of the gluteal (buttock) muscles. Height was measured by making the subject stand against a metric measuring scale. The subjects were asked to stand bare feet on a flat floor against the scale with heels, buttocks, shoulders and occiput touching the scale. The subjects were asked to keep their heads erect with eyes aligned horizontally and ears vertically without any tilt. With the help of a ruler, the topmost point of the vertex was identified on the scale.

\section{RESULTS}

\begin{tabular}{|c|c|c|c|c|}
\hline Group & $\begin{array}{l}\text { Males + } \\
\text { Females } \\
(200)\end{array}$ & $\begin{array}{l}\text { Males } \\
(100)\end{array}$ & $\begin{array}{c}\text { Females } \\
\text { (100) }\end{array}$ & $\begin{array}{l}\text { Comparison of " } p \text { " Value } \\
\text { between Male } \\
\text { \& Female }\end{array}$ \\
\hline $\begin{array}{c}\text { Height } \\
\text { (Metres) }\end{array}$ & $\begin{array}{c}1.67 \pm \\
0.11\end{array}$ & $\begin{array}{l}1.76 \pm \\
0.055\end{array}$ & $\begin{array}{l}1.58 \pm \\
0.077\end{array}$ & $<0.001$ \\
\hline $\begin{array}{l}\text { Weight } \\
\text { (Kg) }\end{array}$ & $\begin{array}{c}73.17 \pm \\
16.66\end{array}$ & \begin{tabular}{|c|}
$85.14 \pm$ \\
11.181
\end{tabular} & $\begin{array}{l}61.20 \pm \\
11.963\end{array}$ & $<0.001$ \\
\hline $\begin{array}{c}\text { BMI } \\
(\mathrm{Kg} / \mathrm{m} 2)\end{array}$ & $\begin{array}{c}26.60 \pm \\
5.03\end{array}$ & \begin{tabular}{|c|}
$27.61 \pm$ \\
4.790
\end{tabular} & $\begin{array}{c}25.59 \pm \\
5.109\end{array}$ & 0.044 \\
\hline $\begin{array}{c}\text { WC } \\
\text { (Metres) }\end{array}$ & $\begin{array}{c}0.83 \pm \\
0.12\end{array}$ & $\begin{array}{l}0.89 \pm \\
0.093\end{array}$ & $\begin{array}{l}0.77 \pm \\
0.107\end{array}$ & $<0.001$ \\
\hline $\begin{array}{c}\text { HC } \\
\text { (Metres) }\end{array}$ & $\begin{array}{c}1.01 \pm \\
0.09\end{array}$ & $\begin{array}{l}1.04 \pm \\
0.067\end{array}$ & $\begin{array}{l}0.97 \pm \\
0.102 \\
\end{array}$ & $<0.001$ \\
\hline WHR & $\begin{array}{c}0.82 \pm \\
0.06\end{array}$ & $\begin{array}{l}0.86 \pm \\
0.057\end{array}$ & $\begin{array}{l}0.78 \pm \\
0.048\end{array}$ & $<0.001$ \\
\hline $\begin{array}{c}\text { TSH } \\
(\mathrm{mIU} / \mathrm{ml})\end{array}$ & $\begin{array}{c}2.66 \pm \\
1.28 \\
\end{array}$ & $\begin{array}{l}2.38 \pm \\
1.481 \\
\end{array}$ & $\begin{array}{l}2.95 \pm \\
0.982 \\
\end{array}$ & 0.058 \\
\hline \multicolumn{5}{|c|}{$\begin{array}{c}\text { Table 1. Mean \& Standard Deviation of Anthropometric } \\
\text { Parameters Related to Obesity and TSH Values Among the } \\
\text { Subjects }\end{array}$} \\
\hline \multicolumn{5}{|c|}{ Values indicate mean \pm standard deviation } \\
\hline
\end{tabular}

Table 1 depicts mean values of anthropometric parameters like Height, Weight, BMI, Waist Circumference (WC), Hip Circumference (HC), Waist Hip Ratio (WHR) are all on the higher side in males in comparison to females. Whereas TSH level is too some extent lower in males in compare to females. Regarding comparison of " $p$ " value between males and females, it has been seen that " $p$ " value is significant in Height, Weight, Waist Circumference, Hip circumference and Waist Hip Ratio ( $p<0.001)$. 

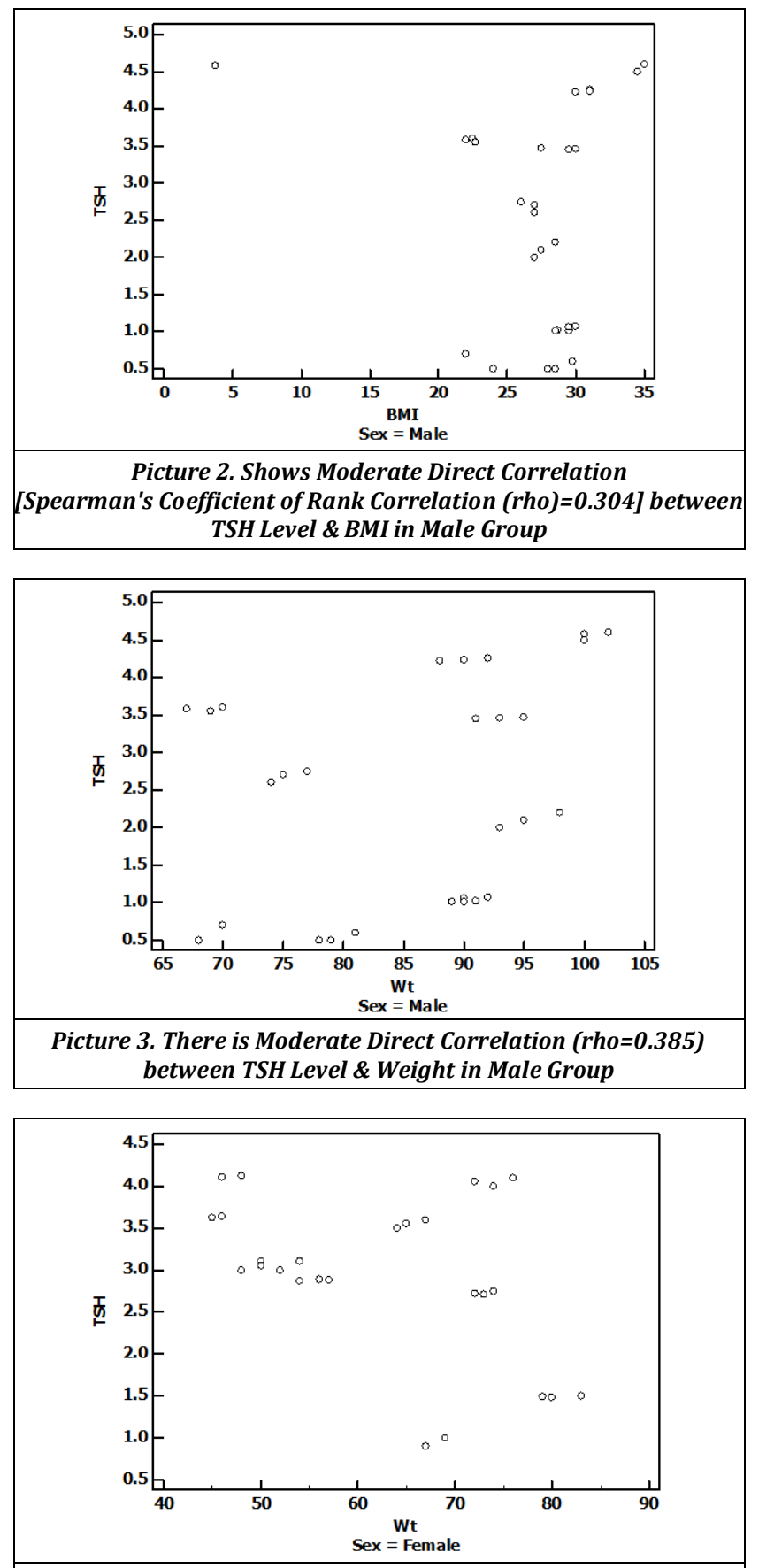

Picture 4. It Shows Moderate Inverse Correlation (rho = -0.495) between TSH Level \& Weight (Wt.) in Female Group

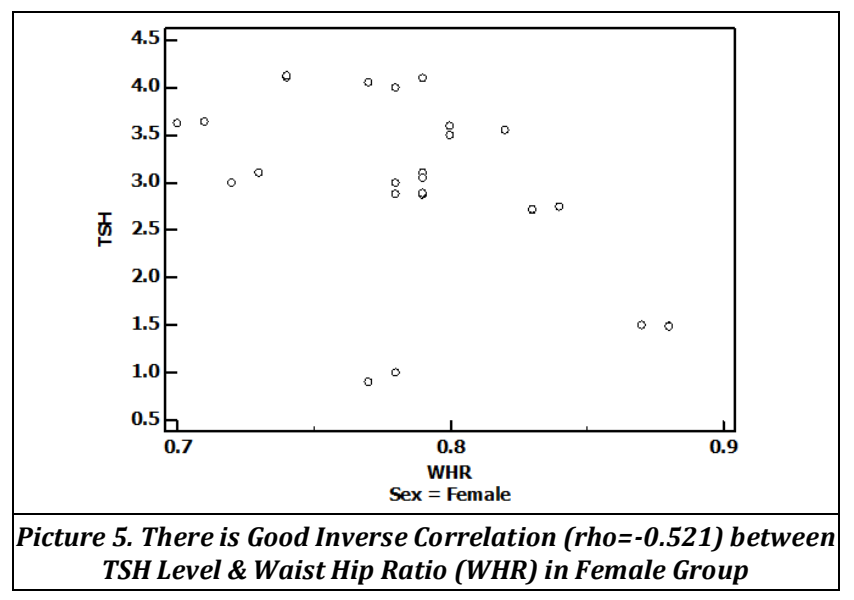

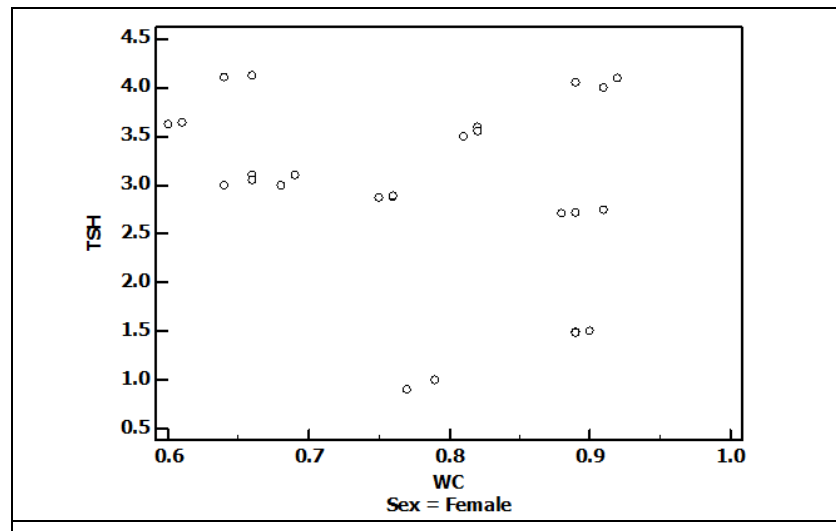

Picture 6. There is Moderate Inverse Correlation (rho=-0.314) between TSH Level \& Waist Circumference (WC) in Female Group

The reading was recorded to the nearest centimetre. Weight was recorded using weighing machine (Adult type) to the nearest kilogram. Subjects were asked to remove shoes and any bulky clothing before recording of weight. Estimation of serum TSH was done in Human serum by Chemiluminescence Immunoassay (CLIA). It is an Immunoenzymometric assay.

\section{DISCUSSION}

In this study, (Table 1) average height of males $(1.76 \pm 0.055$ metres) is greater than the average height of females $(1.58 \pm$ 0.077 metres). Average weight is also higher in males (85.14 $\pm 11.181 \mathrm{kgs})$ than females $(61.20 \pm 11.963 \mathrm{kgs})$. Therefore in this study BMI is more in males $\left(27.61 \pm 4.790 \mathrm{~kg} / \mathrm{m}^{2}\right)$ in comparison to females $\left(25.59 \pm 5.109 \mathrm{~kg} / \mathrm{m}^{2}\right)$.This observation regarding BMI contradicts the findings of Kota SK et al,16 Jung $\mathrm{CH}$ et al ${ }^{15}$ studies where the $\mathrm{BMI}$ is more in the females than males, whereas observation of Mahanta $M$ et al ${ }^{17}$ :- BMI of males $\left(21.41 \pm 2.197 \mathrm{~kg} / \mathrm{m}^{2}\right)$ was slightly more than the females $\left(21.36 \pm 2.995 \mathrm{~kg} / \mathrm{m}^{2}\right)$, to some extent corresponds with the findings of this study.

Average Waist Circumference (WC) of males (0.89 \pm 0.093 metres) is greater than the average $\mathrm{WC}$ of females $(0.77 \pm 0.107$ metres) and average Hip Circumference (HC) is greater in males $(1.04 \pm 0.067$ metres $)$ than females $(0.97 \pm$ 0.102 metres) in this study (Table 1). Therefore, it has been observed Waist-Hip Ratio (WHR) is more in males (0.86 \pm $0.057)$ than in females $(0.78 \pm 0.048)$ in this study. Result of WHR in our study corroborates with observation of Mahanta $\mathrm{M}$ et $\mathrm{al}^{17}$ where WHR in male group $(0.84 \pm 0.059)$ was more than female group $(0.77 \pm 0.048)$.

The present study found that there is no correlation between serum TSH level and height, hip circumference in total subjects, male and female group. On contrary to common observations in various studies, it has been seen that there is no correlation between BMI and serum TSH level in female subjects, whereas there is moderate direct correlation between TSH level and BMI (Pic. 2) and TSH level and Weight (Pic. 3) in male group and there is good inverse correlation between TSH level and WHR in female group (Pic. 5) and, moderate inverse correlation between TSH level and Weight (Pic. 4) and TSH level and Waist Circumference (Pic. 6) in female subjects.

Bastemir $\mathrm{M}$ et $\mathrm{al}^{2}$ found positive and significant correlation between serum TSH level with body weight $(\mathrm{r}=0.231, \mathrm{p}<0.001), \quad$ BMI $\quad(\mathrm{r}=0.270, \quad \mathrm{p}<0.001)$, waist 
circumference $(\mathrm{r}=0.219, \mathrm{p}=0.001)$ in total study group, whereas in the present study TSH level has moderate direct correlation with BMI (rho=0.304, $\mathrm{P}=0.0321$ ) and Weight (rho $=0.385, \mathrm{P}=0.0058$ ) only in male group and good inverse correlation with WHR (rho $=-0.521, \mathrm{P}=0.0001)$ and moderate inverse correlation with Weight (rho $=-0.495, \mathrm{P}=0.0003$ ) and Waist Circumference (rho=-0.314, $\mathrm{P}=0.0266$ ) in female group.

Kundsen $\mathrm{N}$ et al 13 found a positive association between BMI and serum TSH level ( $\mathrm{p}<0.001)$, a negative association between BMI and serum free $\mathrm{T}_{4}$ level and no association between BMI and free $\mathrm{T}_{3}$ level. Therefore, their study suggested that even slightly elevated serum TSH levels are associated with an increase in the occurrence of obesity despite of normal thyroid function. It corroborates with the findings in male population: moderate direct correlation between TSH level and BMI.

Jung $\mathrm{CH}$ et al ${ }^{15}$ performed a study with 66,260 Korean population. They found that overt and subclinical, both groups of hypothyroidism exhibited higher waist to hip ratios, an index of obesity. Whereas in the present study (In 100 clinically euthyroid subjects), there is good inverse correlation between serum TSH level and WHR in female group and no correlation in male group.

Galofre JC et al ${ }^{18}$ performed a study over 144 euthyroid obese male patients (Mean BMI $41.8 \mathrm{~kg} / \mathrm{m}^{2}$ ). They have found a positive correlation between BMI and TSH $(r=0.22 ; \mathrm{p}<0.05)$, as well as between serum baseline Insulin ( $>10 \mathrm{mu} / \mathrm{l})$ and TSH concentration $(\mathrm{r}=0.27 ; \mathrm{p}<0.05)$.It corroborates with the present study where there is moderate direct correlation between TSH level and BMI specially in male group.

Shon HS et al $^{19}$ studied a total of 1572 euthyroid women in a cross-sectional study. They sought to evaluate thyroid function (Free $\mathrm{T}_{4}, \mathrm{TSH}$ ) and its possible relationship with BMI and lipid profiles in euthyroid subjects. After adjustment for age and smoking, TSH was not correlated with BMI which echoes our findings where TSH level has no relation with BMI in female group.

Hari Kumar KVS et al ${ }^{20}$ showed that elevated TSH level (between $4.5-10 \mathrm{~m} \mathrm{IU} / \mathrm{l}$ ) with normal T3, T4 was seen in $4 / 20$ overweight and $9 / 30$ of obese children ( $p=0.5219)$. The mean TSH was comparable in both the groups $(3.22 \pm 3.1 \mathrm{~m}$ IU/L vs. $3.63 \pm 2.2 \mathrm{~m} \mathrm{IU} / \mathrm{L}, \mathrm{p}=0.3491$ ). Overall TSH showed no correlation with BMI ( $\mathrm{r}=0.0014, \mathrm{p}=0.9924)$. They concluded that the preliminary data did not show any relation between severity of obesity and TSH level. In the present study there is no correlation between TSH level and BMI in female subjects but there is moderate direct correlation between TSH level and BMI in male group.

Ambrosi B et al ${ }^{21}$ evaluated serum $\mathrm{TSH}$ and free $\mathrm{T}_{4}$ levels, anthropometric and metabolic parameters in 581 obese patients and they concluded that a relationship between thyroid function and overweight/ obesity condition seems to exist, mainly influenced by insulin resistance. Whether variations in TSH and/or thyroid hormones, within a normal range, can influence body weight or whether obesity per se can alter thyroid function cannot be stated so far. In present study there is a moderate direct correlation between serum TSH level and BMI, a marker for obesity, in male population but no relation in female group. Whereas another marker of obesity, WHR has moderate inverse correlation with BMI in female group.

\section{Limitations}

Our study was not designed to prove or disprove a direct role of thyrotropin in adiposity. It was at best a time bound crosssectional observational study, taking advantage of the availability of structured clinical information on 100 medical and paramedical students selected at random. Only serum TSH has been estimated in study subjects. It is not evident clearly whether increased TSH levels favour the deposition of fat, or, on the contrary, whether excessive accumulation of fatty tissue increases TSH secretion. Other parameters like Serum levels of $T_{3}, T_{4}$, Serum Insulin level or plasma Leptin concentration also need to be measured to find out their effect on various anthropometric parameters. Also, study population is small in number. As this is a time-bound study, it was not possible to conduct this over a large population. Therefore, we cannot construct a cause-effect relationship with our observation. However, there is an urgent need to conduct a longitudinal, long term follow-up study over a large population to establish the reference values and cause- effect relationship between obesity and serum TSH level.

\section{CONCLUSIONS}

There is no correlation between BMI and serum TSH levels in female subjects, whereas there is moderate direct correlation between TSH level and BMI, TSH level and Weight in male group and there is good inverse correlation between TSH level and WHR in female group and moderate inverse correlation between TSH level and Weight, TSH level and Waist Circumference in female subjects.

\section{ACKNOWLEDGEMENT}

We would like to thank the Principal, The Head of Department of Physiology, The Head of Department of Biochemistry and The Head of Department of G \& O of MGM Medical College, Kishanganj, Bihar.

\section{REFERENCES}

[1] Jameson JL, Weetman AP. Disorders of the thyroid gland. In: Fauci AS, Braunwald E, Kasper DL, et al. eds. Harrison's Principles of Internal Medicine. Vol. 2. 17th edn. New York: The McGraw-Hill 2008: p. 2224-47.

[2] Bastemir M, Akin F, Alkis E, et al. Obesity is associated with increased serum TSH level, independent of thyroid function. Swiss Med Wkly 2007;137(2930):431-4.

[3] Sorisky A, Bell A, Gagnon A. TSH receptor in adipose cells. Horn Metab Res 2000;32(11-12):468-74.

[4] Schaffler A, Binart N, Scholmerich J, et al. Hypothesis paper Brain talks with fat -- evidence for a hypothalamic-pituitary-adipose axis? Neuropeptides 2005;39(4):363-7.

[5] Rosenbaum M, Hirsch J, Murphy E, et al. Effects of changes in body weight on carbohydrate metabolism, catecholamine excretion and thyroid function. Am J Clin Nutr 2000;71(6):1421-32.

[6] Valyasevi RW, Harteneck DA, Dutton CM, et al. Stimulation of adipogenesis, peroxisome proliferatoractivated receptor gamma (PPARgamma) and thyrotropin receptor by PPARgamma agonist in human orbital preadipocyte fibroblasts. J Clin Endocrinol Metab 2002;87(5):2352-8. 
[7] Rajala MW, Scherer PE. Minireview: the adipocyte -- at the crossroads of energy homeostasis, inflammation and atherosclerosis. Endocrinology 2003;144(9):3765-73.

[8] Rondinone CM. Adipocyte-derived hormones, cytokines and mediators. Endocrine 2006;29(1):8190.

[9] Menendez C, Baldelli R, Camina JP, et al. TSH stimulates leptin secretion by a direct effect on adipocytes. J Endocrinol 2003;176(1):7-12.

[10] Zimmermann-Belsing T, Brabant G, Holst JJ, et al. Circulating leptin and thyroid dysfunction. Eur J Endocrinol 2003;149(4):257-71.

[11] Danese MD, Ladenson PW, Meinert CL, et al. Effect of thyroxine therapy on serum lipoproteins in patients with mild thyroid failure: a quantitative review of literature. J Clin Endocrinol Metab 2000;85(9):29933001.

[12] Visscher TLS, Seidell JC. The public health impact of obesity. Ann Rev Public Health 2001;22:355-75.

[13] Kundsen N, Laurberg P, Rasmussen LB, et al. Small differences in thyroid function may be important for body mass index and the occurrence of obesity in the population. J Clin Endocrinol Metab 2005;90(7):401924.

[14] De Pergola G, Ciampolillo A, Paolotti S, et al. Free triiodothyronine and thyroid stimulating hormone are directly associated with waist circumference, independent of insulin resistance, metabolic parametres and blood pressure in overweight and obese women. Clin Endocrinol (Oxf) 2007;67(2):2659.

[15] Jung CH, Sung KC, Shin HS, et al. Thyroid dysfunction and their relation to cardiovascular risk factors such as lipid profile, hsCRP and waist hip ratio in Korea. Korean J Intern Med 2003;18(3):146-53.

[16] Kota SK, Meher LK, Jammula S, et al. Obesity and thyrotropinemia: association in Indian adults. Thyroid Research and Practice 2013;10(1):4-7.

[17] Mahanta A, Choudhury B, Choudhury DS. Serum thyrotropin level in relation to obesity indicators in a clinically euthyroid population. International Journal of Physiology 2013;1:7-12.

[18] Galofre JC, Pujante P, Abreu C, et al. Relationship between thyroid-stimulating hormone and insulin in euthyroid obese men. Ann Nutr Metab 2008;53(34):188-94.

[19] Shon HS, Jung ED, Kim SH, et al. Free T4 is negatively correlated with body mass index in euthyroid women. Korean J Intern Med 2008;23(2):53-7.

[20] Harikumar KVS, Verma A, Muthukrishnan J, et al. Obesity and thyrotropinemia. Indian J Pediatrics 2009;76(9):933-5.

[21] Ambrosi B, Masserini B, Iorio L, et al. Relationship of thyroid function with body mass index and insulin resistance in euthyroid obese subjects. J Endocrinol Invest 2010;33(9):640-3. 